\title{
The APPLiCATiOn OF KNOWLEDGE MANAGEMENT ELEMENTS In DyNAMiCAlly Changing ORganisations
}

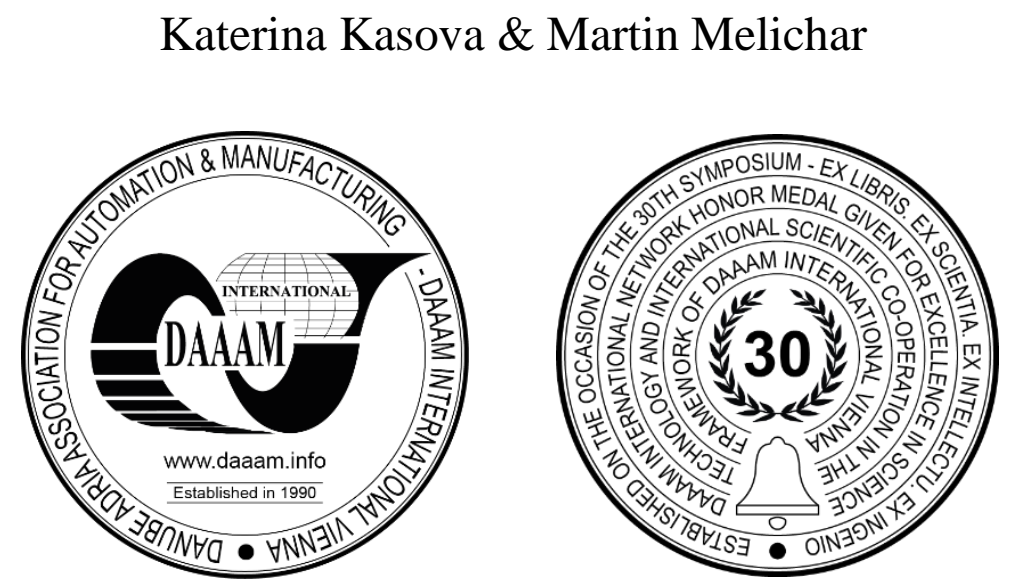

This Publication has to be referred as: Kasova, K[aterina] \& Melichar, M[artin] (2021). The Application of Knowledge Management Elements in Dynamically Changing Organisations, Proceedings of the 32nd DAAAM International Symposium, pp.0666-0672, B. Katalinic (Ed.), Published by DAAAM International, ISBN 978-3-902734-33-4, ISSN 1726-9679, Vienna, Austria

DOI: 10.2507/32nd.daaam.proceedings.094

\begin{abstract}
This paper focuses on the application of the selected knowledge management elements in a dynamically changing organisation. The main research question is how to secure the transfer of knowledge in a team with annual fluctuation of its members. For this single case study, we picked the Formula Student team by the West Bohemian University in Pilsen, which consists of 25-30 students. Part of the investigation is a description of basic terms of knowledge management such as knowledge, information, and data. Then we analyse the organisation, where we found that the current status of knowledge transfer is not satisfactory. Based on the findings, we suggested and applied several knowledge management elements in the organisation. Finally, we defined expected benefits and possible risks related to applying knowledge management in the respective organisation.
\end{abstract}

Keywords: Knowledge; Information; Management; Knowledgeable workers.

\section{Introduction}

If any organisation wants to be perceived differently and uniquely, it is very important to use its technologies and methods in a specific and effective way, different from its competitors. Any organisation needs to be able to master their knowledge and make it to their advantage. This article aims to apply knowledge management elements in the Formula Student team by the West Bohemian University in Pilsen. Regular Formula Student teams comprise 20-60 members, mostly university students of technical majors. The racing period covers the whole academic year and usually, $30 \%$ of the team changes annually. Most of the members stay for 2-5 years and gain enough experience which they pass further to the new members. Especially this feature defines a dynamically changing team where we need to apply knowledge management elements.

\section{Knowledge management}

Many publications have been written about knowledge management. [1], [2], [3] These publications focus mostly on knowledge management on its general level or describe its application in large corporations. Knowledge management development goes hand in hand with data, information, and knowledge collection. 
Knowledge management helps companies to increase their ability to succeed and is successfully used by educational institutions and in the cooperation among various companies. [4] To successfully exploit knowledge management benefits, it is necessary to further develop intellectual capital and informational technologies. Our time is characterised by easily accessible information. This accessibility goes together with the need to correctly identify the necessary information, get rid of the unnecessary ones, and process them effectively, which is very difficult and time-consuming. Knowledge management ensures this information will be used effectively. [1]. The main goal of knowledge management is to provide organisations with a set of tools and methods, that make their efforts more effective. Most organisations work with knowledge but without any primary rules, which means they don't necessarily reach their desired goals. [2]

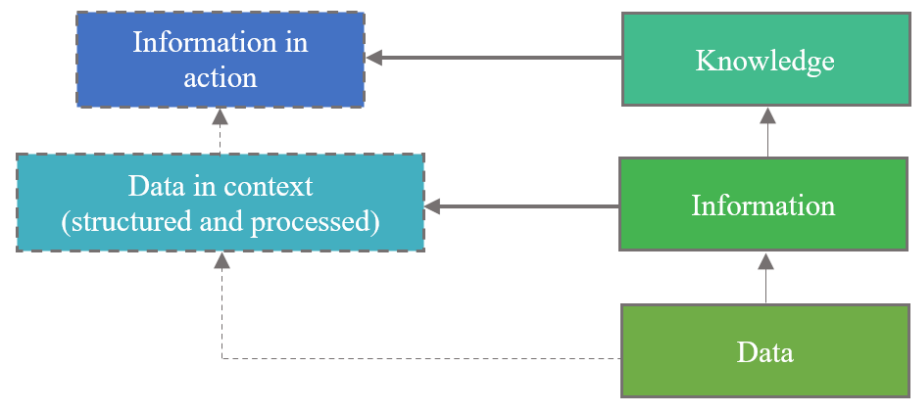

Fig. 1. Relations between data, information, and knowledge

Knowledge assumes various preconditions and experience should be used while working with knowledge. Hence, you can express knowledge with this formula:

$$
\text { knowledge }=\text { information }+x
$$

where $x$ is the amount of familiarity, experience, skills, mental relations, values, and principles obtained in the past.[5]

\section{Definition of the term organisation for the use of knowledge management}

The theory is applied to the Formula Student team, which now has 20 active members and 15 new members. Formula Student is a prestigious competition organised by SAE International. There are usually 540 competing teams from technical universities. [6] It's the most famous technical competition that focuses on developing young people and motivate them to take further steps in their education by a very intensive experience in the field of design and production while having to consider economic aspects as well. [7]

\subsection{Formula Student team knowledge management requirements}

The Formula Student team has partly specific requirements compared to regular racing teams or organisations. The requirements are keeping a very high level of information sharing among most members, quick accessibility, timing, and validity. This is caused mostly by a high fluctuation of members as desired based on the philosophy of the whole competition. A regular Formula Student team comprise 20-60 students of various classes, while roughly 20-30\% of the members change every year. Therefore, there's a huge need for swift information transfer and knowledge management in general.

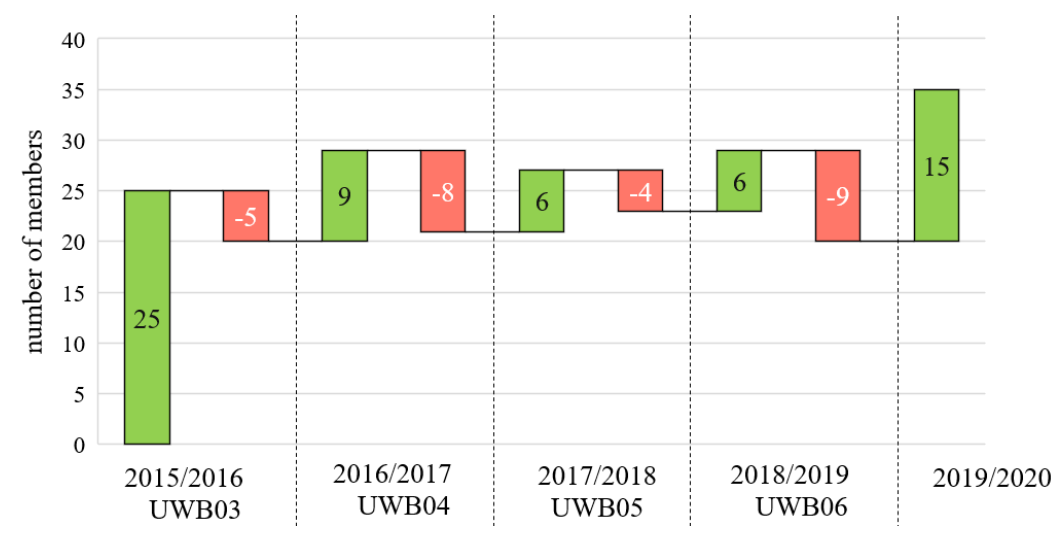

Fig. 2. Evolution of the Formula Student team member's number 
Fig. no. 2 shows the number of members in the Formula Student Team by the West Bohemian University in Pilsen. (The total number of members is seen on the "Number of members" axis, the red columns show the number of leaving members at the end of every season. The green columns show newly entered members at the beginning of every new season.) Based on these data, the fluctuation is roughly $30 \%$ of all members annually. The main benefit of knowledge management application expected by the team is a more effective way of knowledge transmission among the individual members without losing the important know-how in between various racing seasons.

The Formula Student is a highly competitive and dynamic environment, where innovation and development play a significant role. It is not uncommon for leading teams to lose their position quickly when not reflecting the fast pace of necessary changes. They might fall from the top of the race to middle or low positions. Hence, if teams want to be successful, they must judge the situation quickly and avoid repeating mistakes or less functional solutions. It is important to see the opportunities, quickly use them or abandon them, based on the situation. To achieve this in a long-term horizon, it is essential to have the data, information, and knowledge from the past seasons and use them effectively.

\section{Data collection and evaluation}

To effectively choose and apply the knowledge management elements with the greatest benefit for the team, it is important to map the status, processes, and knowledge transfer across the team.

- Main knowledge and skills: With the leading workers, we defined the most important knowledge and skills necessary to designing and producing a new racing car and to ensure the everyday operations throughout the racing season and at the race itself. These essential knowledge and skills are quickly transforming into various new types of knowledge. It would be very difficult, even impossible, to realise the whole project without this knowledge. Therefore, the human and intellectual capital is essential for a successful realisation. The knowledge varies from administrative, to design, up to the construction and operations of the vehicle at the race.

- Respective position within the team: To keep up with the rules of the competition, it is important to perform a lot of essential tasks every season. And on top of that, if any teams aim to score on the top, it is essential to do even more than that. Therefore, we mapped the following positions (Fig 3), which are essential to ensure the operation. These positions have been defined based on historical experience

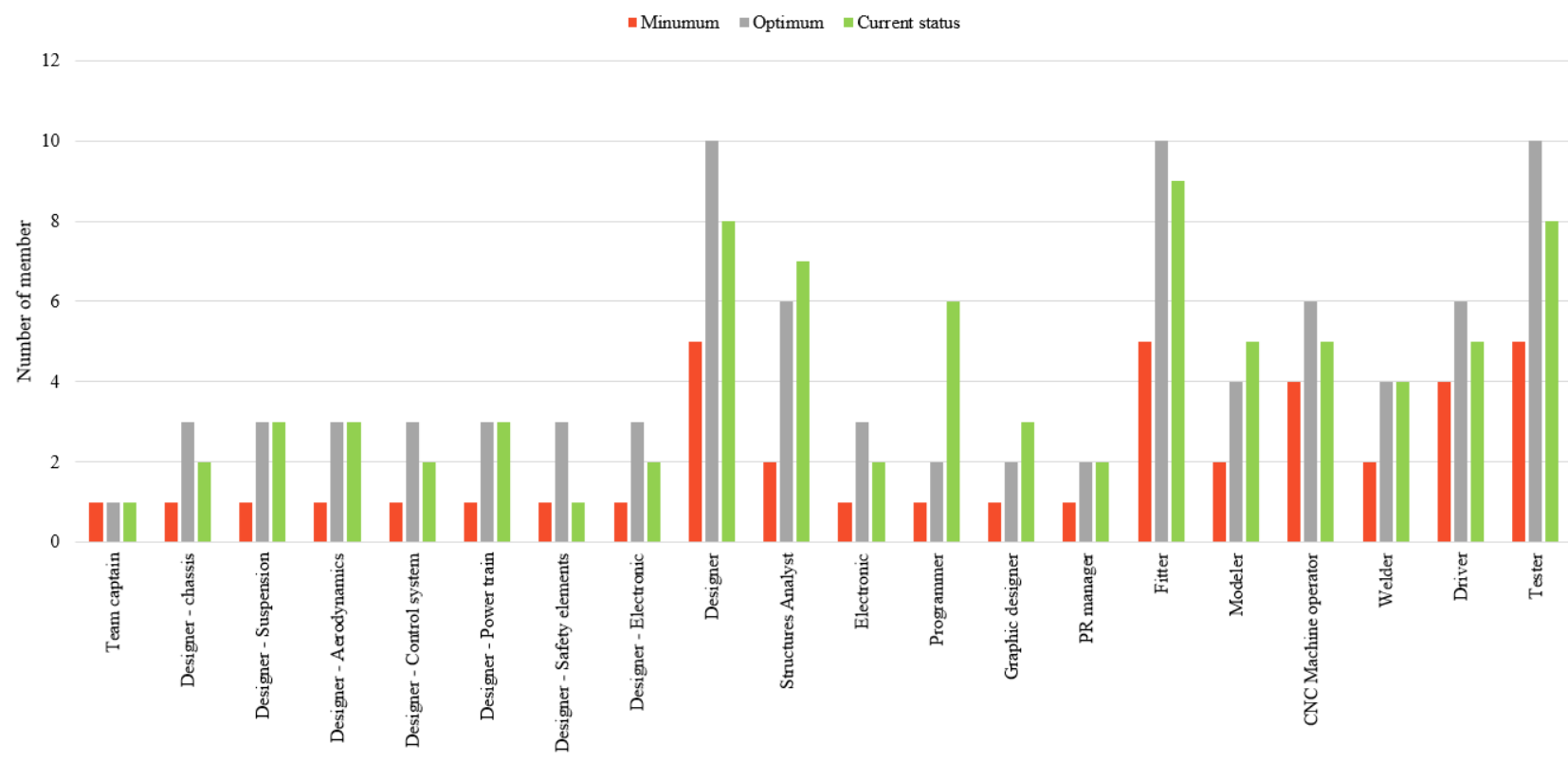

Fig. 3. Comparison of the actual status and desired status

- Current communication and knowledge sharing process: Every type of communication is suitable for various situations and adds another value to the knowledge transfer. Therefore, we distributed a survey where we asked more experienced members to rate various communication tools based on their effective knowledge transfer. In total, 15 members filled out the survey. As you can see in the next Fig. 4, it is evident that the most effective tool is face-toface communication, such as meeting/brainstorming sessions, personal meetings and/or conversations with authority, and practical demonstrations. Furthermore, diaries and news have been rated as another effective way of knowledge transfer. 


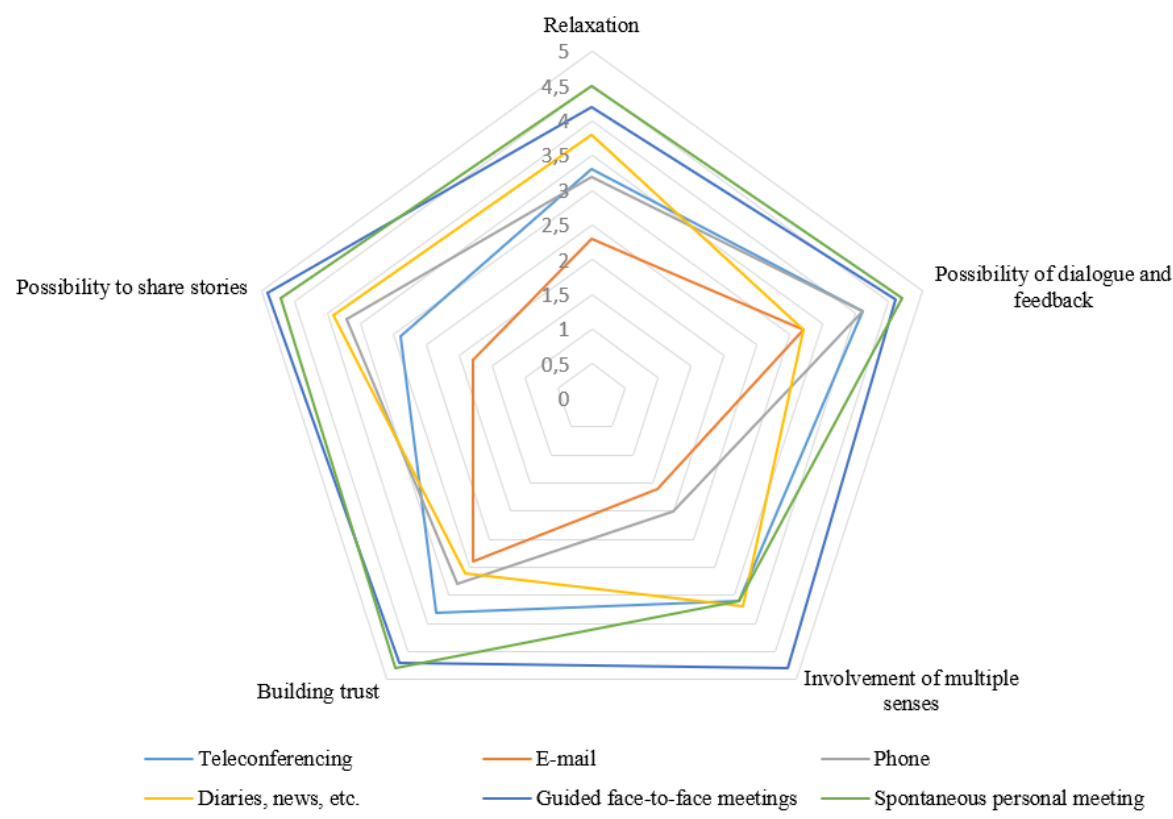

Fig. 4. Knowledge transfer survey - results

While evaluating the overall situation, we found out that the status is not suitable for easy and organized information access for the new members and the regular members as well. Information gets lost due to the big amount of data, information, and knowledge or, on the other hand, duplicity occurs very often. Generally, information transfer occurs verbally in a form of a certain apprenticeship. This system is not suitable due to the high fluctuation of the members and time consumption of the informational transfer. Therefore, much information gets lost when any person leaves the team. In terms of future team management, applying knowledge management seems like an important step. Systematic effort to save and store the knowledge in the team would decide whether the team will be successful in the future or not.

\section{Knowledge management elements application}

Based on the knowledge status analysis in the Formula Student team, we choose and applied the following knowledge management elements: main knowledge definition, key workers definition, process setup, knowledge sharing, and targeted education. These elements should strengthen processes in knowledge management control to make possible the creation of new ways of work and to further develop know-how, find suitable ways of knowledge presentation, and put them to use for further application, revision, preservation, and verification in Fig. 5. [8]

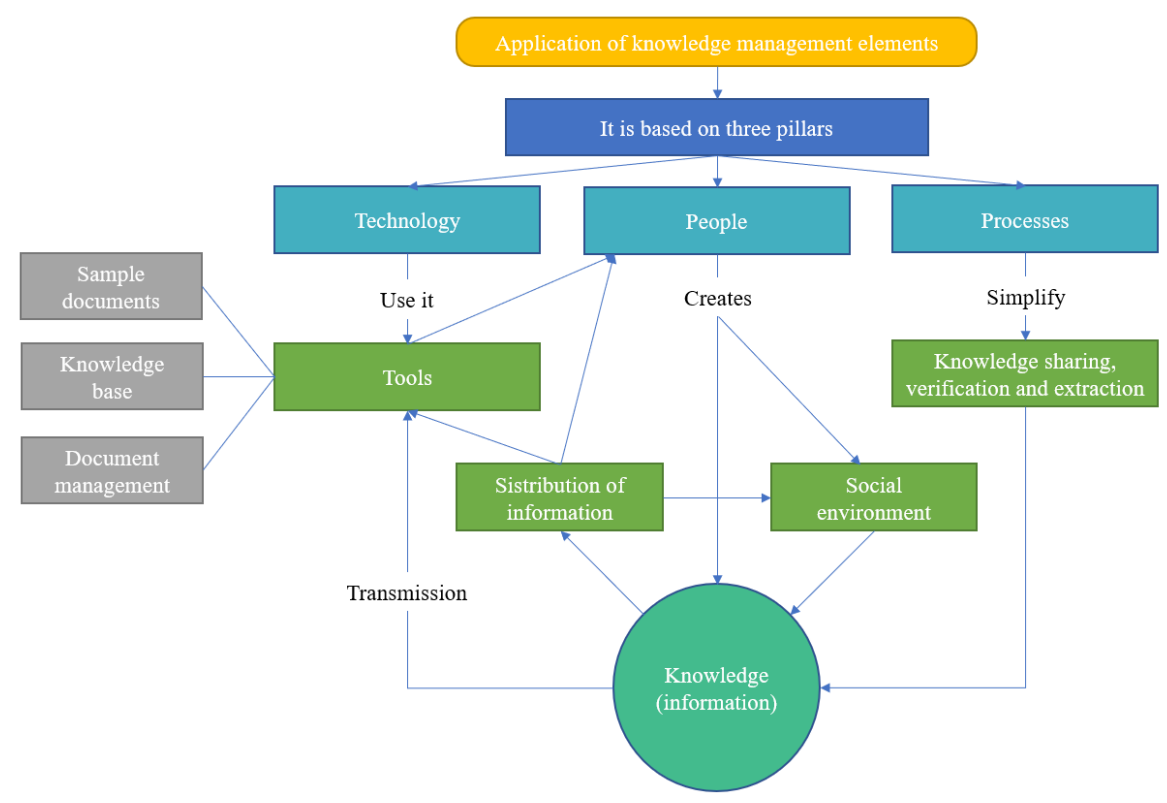

Fig. 5. Use of knowledge management elements 


\subsection{Main knowledge and core workers identification}

To identify the main knowledge in the team, it was necessary to perform a status analysis, which was based on the communication among the team members and the breakdown of individual processes. It was also important to consider the long-term goals and visions. We had to consider not just the internal knowledge but to map the external knowledge (such as the knowledge of the competing teams) as well.

Of all the workers defined by the organisational structure, we picked those members (with the help of current members), which have unique knowledge and therefore, we can mark them as the key workers. [9] We defined five key workers with knowledge covering all the unique knowledge throughout the project and assigned key knowledge as demonstrated in Table 1.

\begin{tabular}{|c|c|c|c|c|c|c|}
\hline & Knowledge & 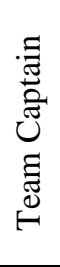 & 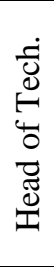 & 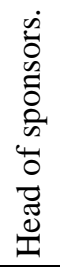 & 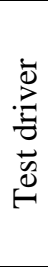 & 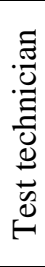 \\
\hline 1. & Knowledge of Formula Student rules & - & - & & & - \\
\hline 2. & Knowledge of the technical solutions of competing teams & - & - & & - & \\
\hline 3. & Estimation of future competitive intentions & & - & & & \\
\hline 4. & Knowledge of team management & $\mathbf{a}$ & - & & & \\
\hline 5. & Knowledge of the possibilities of technical solutions & & - & & & \\
\hline 6. & Knowledge of design solutions & & - & & & \\
\hline 7. & Selection of participation in races from the formula program & - & - & - & & \\
\hline 8. & Selection of team members to participate in specific races & $\mathbf{a}$ & & & & \\
\hline 9. & Provision of conditions at the site of the plant & & - & & & \\
\hline 10. & Knowledge of possible solutions for individual structural nodes & & - & & & \\
\hline 11. & Knowledge of the team's production capabilities & & - & & & - \\
\hline 12. & Knowledge of possible support at the UWB & $\mathbf{\square}$ & & - & & \\
\hline 13. & Knowledge of automotive equipment producers in the region & $\mathbf{a}$ & - & & & \\
\hline 14. & Knowledge of business creation & - & & - & & \\
\hline 15. & Knowledge of advertising rules and possible tax breaks & & & - & & \\
\hline 16. & Knowledge of advertising and sponsorship contracts & & & - & & \\
\hline 17. & Estimate of financing of other formula teams & $\mathbf{a}$ & & - & & \\
\hline 18. & Knowledge of the paraments affecting formula performance & & - & & - & $\mathbf{\square}$ \\
\hline 19. & Knowing how each node's function will work on formula performance & & - & & - & $\mathbf{\square}$ \\
\hline 20. & Knowledge of the possibility of loading individual parts of a formula & & - & & & $\mathbf{n}$ \\
\hline 21. & Knowledge of the real driving characteristics of the formula & & & & - & \\
\hline 22. & Knowledge of the theoretical driving characteristics of a formula & & - & & & $\mathbf{\square}$ \\
\hline
\end{tabular}

Table 1. Main knowledge identification

\subsection{Knowledge sharing process setup}

Among main goals of knowledge management, you can find knowledge identification, use of know-how, experience, and skills exploitation. Furthermore, another goal is to make sure all the above-mentioned would be shared and used further, as necessary. Doing that improves the overall quality, productivity, and the effectivity of work. It should be a task for most knowledgeable workers to provide their knowledge to other team members, who can then perform better and avoid mistakes. Another very important aspect is to be able to preserve the transferred knowledge to make sure the knowledge remains in the team even if the key worker leaves. [10]

It is also important to transfer the knowledge in a continuous way as the average time people spend in team is $2-4$ years. A good example of knowledge transfer (among the drivers in Fig. 6) is when the test driver can convey the knowledge of handling and current power of the power unit to ensure the driver would use the right gear ratio in a suitable driving regimen. This significantly shortens the testing period of new drivers. 


\begin{tabular}{|c|c|c|c|c|c|c|c|}
\hline \multicolumn{6}{|c|}{ Head of Technical Department } & & \multirow[b]{2}{*}{$\begin{array}{l}\text { Team Leader } \\
\text { Testing }\end{array}$} \\
\hline $\begin{array}{c}\text { Team Leader } \\
\text { Aerodynamics }\end{array}$ & $\begin{array}{l}\text { Team Leader } \\
\text { Chassis }\end{array}$ & $\begin{array}{l}\text { Team Leader } \\
\text { Suspension }\end{array}$ & $\begin{array}{l}\text { Team Leader } \\
\text { Power train }\end{array}$ & $\begin{array}{c}\text { Team Leader } \\
\text { Control and safety elements }\end{array}$ & $\begin{array}{l}\text { Team Leader } \\
\text { Electronic }\end{array}$ & & \\
\hline $\begin{array}{l}\text { Designer } \\
\text { Front wing }\end{array}$ & $\begin{array}{l}\text { Designer } \\
\text { Monocoque }\end{array}$ & $\begin{array}{l}\text { Designer } \\
\text { Front axle }\end{array}$ & $\begin{array}{l}\text { Designer } \\
\text { Air intake }\end{array}$ & $\begin{array}{l}\text { Designer } \\
\text { Pedal system }\end{array}$ & $\begin{array}{c}\text { Designer } \\
\text { Electronic units }\end{array}$ & & Test driver \\
\hline $\begin{array}{l}\text { Designer } \\
\text { Rear wing }\end{array}$ & $\begin{array}{c}\text { Designer } \\
\text { Rear part chassis }\end{array}$ & $\begin{array}{l}\text { Designer } \\
\text { Rear axle }\end{array}$ & $\begin{array}{l}\text { Designer } \\
\text { Engine unit }\end{array}$ & $\begin{array}{c}\text { Designer } \\
\text { Steering wheel / dashboard }\end{array}$ & $\begin{array}{l}\text { Designer } \\
\text { Cabling }\end{array}$ & & Driver \\
\hline $\begin{array}{l}\text { Designer } \\
\text { Body }\end{array}$ & & $\begin{array}{l}\text { Designer } \\
\text { Steering }\end{array}$ & $\begin{array}{l}\text { Designer } \\
\text { Exhaust }\end{array}$ & $\begin{array}{c}\text { Designer } \\
\text { Impact element }\end{array}$ & Programmer & $\longrightarrow$ & $\begin{array}{l}\text { Testing } \\
\text { Technician }\end{array}$ \\
\hline \multirow[t]{2}{*}{$\begin{array}{l}\text { Designer } \\
\text { Diffuser }\end{array}$} & & $\begin{array}{l}\text { Designer } \\
\text { Breake system }\end{array}$ & $\begin{array}{l}\text { Designer } \\
\text { Cooling }\end{array}$ & $\begin{array}{c}\text { Designer } \\
\text { Driver protection elements }\end{array}$ & & & $\begin{array}{l}\text { Specialist } \\
\text { for data coll. }\end{array}$ \\
\hline & & & $\begin{array}{c}\text { Designer } \\
\text { Lubrication system }\end{array}$ & & & & $\begin{array}{c}\text { Electrical } \\
\text { engineering }\end{array}$ \\
\hline
\end{tabular}

\subsection{Team members education}

Fig. 6. Test drive knowledge transfer scheme

A new educational system has been designed for the team members to ensure sufficient and effective knowledge and experience transfer and support the introduction and application of various knowledge management elements. Among others, important features of the system are hands-on experience training, a one-week introductory course, mentoring of the new members (every new member has a mentor to obtain the necessary experience and knowledge in the very first weeks in the team), and support courses from external partners.

\section{Main expected benefits and possible risks}

A comparable level of knowledge and skills of the individual members is an essential precondition for national and international success. It is important to stress that fundamental improvement might be reached only through synergy when various elements of knowledge management enhance each other. Knowledge management by itself can't guarantee $100 \%$ success. [11] Fundamental benefits that can be obtained via knowledge management are innovation capacity augmentation - better use of human and other resources, quality improvement. Faster reaction period - higher flexibility, speed and correctness of decisions, more effective team education. Improvement of inner qualities - more effective process innovation, morale, and operational effectivity. More benefits can be seen from the point of view of managers and leaders. It helps them to easily and timely define the knowledge, key performers, key skills and experience, and to improve communication channels, management tools, and strategy tools. [2]

\subsection{Risks}

Applying knowledge management elements in the team presents a big challenge because every project is different and bears various risks and issues related to the realisation. Successful implementation and use of suggested solutions might be hindered especially by change avoidance, fear of the unknown, unwillingness to share information, lack of support from the leadership, not clearly defined responsibilities, lack of ability to recognise knowledge and possibilities of their application, lack of practical use of knowledge, frustration because of wrong expectations and more. Some of the abovementioned situations might be prevented by monitoring the risks and evaluating the possibilities of their occurrence. The selected issues and related solutions are presented in the following overview Table 2.

\begin{tabular}{|l|l|l|}
\hline Problems & Possible risks & Risk lowering/eliminating measurements \\
\hline Goal definition & $\begin{array}{l}\text { Not defining milestones. } \\
\text { Defining unmeasurable milestones. }\end{array}$ & $\begin{array}{l}\text { Defining measurable and clear milestones, regular } \\
\text { information sessions. }\end{array}$ \\
\hline $\begin{array}{l}\text { Factual, time, and } \\
\text { financial range. }\end{array}$ & $\begin{array}{l}\text { Clearly defined scope. } \\
\text { Missing on the time frame. } \\
\text { Exceeding the estimated costs. }\end{array}$ & $\begin{array}{l}\text { Dividing the process into several phases. Controlling the } \\
\text { progress. Primarily focusing on the knowledge chains, } \\
\text { not only on the used technologies. }\end{array}$ \\
\hline $\begin{array}{l}\text { Implementation } \\
\text { process }\end{array}$ & $\begin{array}{l}\text { Uncontrolled transfer of information. } \\
\text { Overly technical approach. } \\
\text { Unclear leadership and low level of } \\
\text { support. }\end{array}$ & $\begin{array}{l}\text { Choose a responsible authority. Inform periodically the } \\
\text { key members of the overall progress. The realisation } \\
\text { must be supported by leading authorities, who should be } \\
\text { able to motivate others. }\end{array}$ \\
\hline $\begin{array}{l}\text { Measuring the } \\
\text { expected benefits }\end{array}$ & $\begin{array}{l}\text { Lack of capability to evaluate } \\
\text { success/failure of individual steps. } \\
\text { Result don't match the expectations. }\end{array}$ & $\begin{array}{l}\text { Inform everyone about the success/failure as soon as } \\
\text { possible. Request feedback from the key members } \\
\text { regularly. Regular checks of progress, goals achievement } \\
\text { and the overall benefits. }\end{array}$ \\
\hline
\end{tabular}

Table 2. Possible risk related to realisation and countermeasures 


\section{Conclusion}

This paper investigates the application of knowledge management in a dynamically changing team. The main research concern is how to secure the knowledge transfer in a team with a very high (annual) fluctuation of the members. The subject of research in this single case study is the Formula Student team of the University of West Bohemia, composed of 20-35 students. Roughly 20-30\% of the members change every year. In the theoretical part, we described the term knowledge and its relation to data and information. To define appropriate applicable elements, we used the status analysis. We defined the main knowledge and skills necessary to ensure the functioning of the team, job positions included. Furthermore, we applied the member education process, which describes the possibilities of transferring the knowledge/information on the new members of the team especially. Figure 2 shows an example of the knowledge transfer between the test drive pilot and other members of the realisation team. All the applied elements of knowledge management might be effectively used as tools to ensure knowledge transfer in the long-term horizon. In the final part of this paper, we described the benefits and risks of applying the knowledge management elements. Among the biggest benefits are innovation capacity augmentation, faster reaction period, and improvement of the inside qualities. On the other hand, among the biggest risks is the unwillingness of the team members to provide and convey the information verbally. Another area for improvement, and thus the idea for further research, would be the possibility of applying an information knowledge base to the assessed team, which is now missing here.

\section{Acknowledgments}

The article contribution has been prepared under project SGS-2019-008.

\section{References}

[1] Davenport, T. H. \& Prusak, L. (1998). Working knowledge: how organizations manage what they know, Harvard Business School Press, ISBN 978-0-87584-655-2, Boston

[2] Pasher, E. \& Ronen, T. (2011). The complete guide to knowledge management: a strategic plan to leverage your company's intellectual capital, John Wiley, ISBN 978-0-470-88129-3, Hoboken.

[3] Collison, Ch. \& Parcell G. (2005). Knowledge management: praktický management znalostí z prostředí předních světových učících se organizací, Computer Press, ISBN 80-251-0760-4, Brno

[4] Majstorovic, V. \& Majstorovic, A (2020): Strategic and Cultural Dimension of the Management by Projects, Proceedings of the 31st DAAAM International Symposium, pp.0049-0055, B. Katalinic (Ed.), Published by DAAAM International, ISBN 978-3-902734-29-7, ISSN 1726-9679, Vienna, Austria

[5] Vymetal, J.; Diacikova, A. \& Vachova, M. (2005). Informační a znalostní management v praxi, LexisNexis, ISBN 80-86920-01-1, Praha

[6] https://mazur-events.de/fs-world/C/, (2020). Formula Student Combustion - World Ranking List, Accessed on: 2020-02-12

[7] https://fsaeonline.com/, (2021). Formula Student General Inforamtion, Accessed on: 2021-09-15

[8] Senge, P. (2006). The fifth discipline: the art and practice of the learning organization, Doubleday, ISBN 9780385517256, New York

[9] Mladkova, L. (2005). Management znalostí, Oeconomica, ISBN 80-245-0878-8, Prague

[10] Bettiol, M.; Di Maria, E. \& Micceli, S. (2020). Knowledge management and industry 4.0: new paradigms for value creation, Springer International Publishing, ISBN 978-3-030-43588-2

[11] Schopflin, K. \& Walsh, M. (2019). Practical knowledge and information management, Facet Publishing, ISBN 9781-78330-335-9, London 